\title{
PENERAPAN RESTORATIVE JUSTICE DALAM TINDAK PIDANA PERZINAAN PADA MASYARAKAT KUTAI ADAT LAWAS
}

\author{
Rosdianaa, Ulum Janah ${ }^{b}$
}

\begin{abstract}
ABSTRAK
Kesadaran akan penyelesaian melalui peradilan formal umumnya masih dirasakan kurang memberikan keadilan bagi korban, seringkali masih menyimpan ketidakpuasan korban atas sanksi pidana yang dijatuhkan kepada pelaku oleh pengadilan. Oleh karenanya, penerapan keadilan restoratif dalam penyelesaian delik adat secara musyawarah mufakat dalam bentuk perdamaian adat masih menjadi primadona dalam menyelesaikan delik adat. Penyelesaian antara pelaku dan korban secara kekeluargaan ataupun melalui peradilan adat merupakan penyelesaian dengan mencari keadilan hakiki. Penelitian ini dilakukan dengan metode sosiologis. yaitu penelitian studi empiris, penelitian yang berorientasi pada aspek hukum dan aspek non hukum yakni mengkaji dan menganalisis bekerjanya hukum dalam masyarakat dengan penerapan restorative justice dalam tindak pidana perzinaan pada Masyarakat Kutai Adat Lawas. Hasil penelitian menunjukan bahwa penyelesaian tindak pidana perzinahan pada Masyarakat Kutai Adat Lawas menerapkan konsep restorative justice, yang model penyelesaiannya ditentukan oleh ketua adat, atau melalui peradilan adat. Keadilan restoratif ini diterapkan dalam penyelesaian tindak pidana perzinahan sebagai upaya untuk memulihkan penderitaan yang dialami korban dan untuk memperbaiki keseimbangan masyarakat. Sanksi bagi pelaku zina bukan sanksi fisik tetapi sanksi berupa pengganti kerugian atau denda yang dikenakan atas perbuatan yang dilakukan. Jika kejadian perselingkuhan terjadi selama 3 (tiga) kali dan yang melakukan orang yang sama maka menggunakan hukum positif yaitu hukum pidana.
\end{abstract}

Kata kunci: adat; perzinahan; restorative justice.

\section{ABSTRACT}

The awareness of settlement with formal justice mostly does not offer satisfactory towards the victim, often times the victim still holds grudge and does not satisfied with the punishment given to the perperator. Therefore, the settlement of offense consetuede with restorative justice is the pre-eminent choice to solve the problem. The settlement between the perperator and the victim with kinship or customary court is really essential. This research is using sociology methods, that is an empirical study oriented towards legal \& non legal aspects which is examine \& analyze the work of law within the society with the application of restorative justice in criminal act of adultery in the Society of Kutai Adat Lawas. The result of the the research is to show that settlement of criminact act of adultery in Society of Kutai Adat Lawas apply the restorative justice, that the solving model is determined by the chief of the society, or customary justice. This restorative justice applied to solve the criminal act of adultery in attempt to console the victim and the harmony of the society. The penalty for the adultery perparator is not a physical punishment but with a fine worth of the criminal that has been done. If the same person did an affair 3 times, then the y use the positive punishment which is the criminal law.

Keywords: adultery; customary; restorative justice.

\footnotetext{
a Fakultas Sastra Universitas Balikpapan, Jalan Pupuk Raya Kelurahan Gunung Bahagia, Balikpapan Kalimantan Timur, email: rosdiana@uniba-bpn.ac.id.

b Fakultas Sastra Universitas Balikpapan, Jalan Pupuk Raya Kelurahan Gunung Bahagia, Balikpapan Kalimantan Timur, email: ulum.jannah@uniba-bpn.ac.id.
} 


\section{PENDAHULUAN}

Negara Indonesia merupakan negara yang memiliki wilayah yang sangat luas dan terbentang dari sabang sampai merauke serta negara Indoensia memiliki berbagai macam suku, ras, agama dan adat kebiasaan yang tersebar baik di kota maupun di desa. Selain itu, dalam kehidupan bermasyarakat antara hukum dan masyarakat merupakan dua hal yang tidak dapat dipisahkan seperti adagium ibi ius ibu societas yang artinya di mana ada masyarakat di situ ada hukum. Oleh karena itu dibutuhkan suatu aturan hukum untuk mengatur kehidupan bermasyarakat demi mencapai ketertiban umum. Aturan hukum tersebut ada yang tertulis maupun yang tidak tertulis dan aturan tersebut berlaku secara nasional maupun kedaerahan baik di dalam lapangan hukum publik maupun hukum privat.

Negara Indonesia adalah negara hukum (rechtsaat), di mana setiap ketentuan yang berlaku selalu berpedoman kepada suatu sistem hukum yang berlaku secara nasional. Namun, di samping berlakunya hukum nasional di tengah masyarakat juga tumbuh dan berkembang suatu sistem hukum, yang bersumber dari kebiasaan yang ada di masyarakat tersebut. Kebiasaan ini yang nantinya berkembang menjadi suatu ketentuan yang disebut dengan hukum adat.

Eksistensi hukum adat sebagai salah satu bentuk hukum yang diakui keberadaannya dalam kehidupan dan budaya hukum masyarakat Indonesia tercantum pada Undang-Undang Dasar Negara Republik Indonesia Tahun 1945 pada Pasal 18B Ayat (2) yang menentukan "Negara mengakui dan menghormati kesatuan-kesatuan Masyarakat Hukum Adat beserta hak-hak tradisionalnya sepanjang masih hidup dan sesuai dengan perkembangan masyarakat dan prinsip Negara Kesatuan Republik Indonesia, yang diatur dalam undang-undang". Penjelasan mengenai pengakuan hukum adat oleh Negara juga terdapat pada Pasal 27 ayat (1) Undang-Undang Dasar Negara Republik Indoensia Tahun 1945 menyebutkan bahwa "Segala warga Negara bersamaan kedudukannya di dalam hukum dan pemerintahan dan wajib menjunjung hukum dan pemerintahan itu dengan tidak ada kecualinya", berdasarkan rumusan ketentuan tersebut dapat ditarik kesimpulan bahwa baik warga sipil maupun aparatur pemerintahan tanpa terkecuali diwajibkan untuk menjunjung hukum yang berlaku dalam kehidupan dan budaya hukum masyarakat Indonesia baik itu hukum pidana, hukum perdata, maupun hukum adat.

Masyarakat hukum adat diatur juga dalam Pasal 6 ayat (1) Undang-Undang Nomor 39 Tahun 1999 Tentang Hak Asasi Manusia (HAM) menyebutkan bahwa "Dalam rangka penegakan hak asasi manusia, perbedaan dan kebutuhan dalam masyarakat hukum adat harus diperhatikan dan dilindungi oleh hukum, masyarakat, dan pemerintah." Sedangkan penjelasan Pasal 6 ayat (1) undangundang tersebut menyebutkan bahwa hak adat yang secara nyata masih berlaku dan dijunjung tinggi di dalam lingkungan masyarakat hukum adat harus dihormati dan dilindungi dalam rangka 
Penerapan Restorative Justice dalam Tindak Pidana Perzinaan pada Masyarakat Kutai Adat Lawas

perlindungan dan penegakan hak asasi manusia dalam masyarakat yang bersangkutan dengan memperhatikan hukum dan peraturan perundang-undangan.

Hukum adat merupakan salah satu bentuk hukum tidak tertulis yang masih hidup dalam kehidupan masyarakat hukum adat di Indonesia. Perlu diketahui pula bahwa Hukum Adat merupakan salah satu bentuk hukum yang berlaku dalam kehidupan dan budaya hukum masyarakat Indonesia yang masih berlaku sampai dengan saat ini. Eksistensi hukum adat dapat dilihat hingga saat ini melalui adanya peradilan-peradilan adat serta perangkat-perangkat hukum adat yang masih dipertahankan oleh masyarakat hukum adat di Indonesia untuk menyelesaikan berbagai sengketa dan delik yang tidak dapat ditangani oleh lembaga kepolisian, pengadilan, serta lembaga pemasyarakatan. Hukum adat tetap dipertahankan hingga saat ini oleh masyarakat hukum adat sebab mereka percaya bahwa putusan yang dikeluarkan melalui peradilan adat terhadap suatu delik yang diadili peradilan adat dapat memberikan kepuasan akan rasa keadilan, serta kembalinya keseimbangan dalam kehidupan masyarakat adat atas keguncangan spiritual yang terjadi atas berlakunya delik adat tersebut.

Kesadaran akan penyelesaian melalui peradilan formal (Pengadilan Negeri) umumnya masih dirasakan kurang memberikan rasa keadilan bagi korban, dan seringkali masih menyimpan ketidakpuasan (dendam) dari korban (keluarga korban) atas hukuman atau sanksi pidana yang telah dijatuhkan kepada pelaku oleh pengadilan. Oleh karena itu, penerapan keadilan restoratif dalam penyelesaian delik adat secara musyawarah mufakat dalam bentuk perdamaian adat masih menjadi primadona masyarakat dalam menyelesaikan delik adat yang terjadi.

Bentuk penyelesaian antara pelaku dan korban secara kekeluargaan ataupun melalui lembaga peradilan adat ini merupakan bentuk penyelesaian yang bertujuan mencari keadilan yang hakiki, yang dalam kenyataannya mirip dengan konsep keadilan restotratif (restorative justice). Konsep keadilan restoratif digagas oleh pelaku dan korban untuk menyelesaikan persoalan secara damai dengan mengutamakan prinsip musyawarah dan mufakat.

Konsep keadilan restoratif ini sesunggguhnya sudah lama diterapkan oleh masyarakat hukum adat di berbagai wilayah di Indonesia dalam rangka penyelesaian delik adat yang terjadi atau dalam menyelesaikan kasus tindak pidana ringan. Namun baru akhir-akhir ini konsep keadilan restoratif muncul kembali disaat kepercayaan masyarakat terhadap peradilan formal mulai luntur, putusan pengadilan tidak lagi dapat memberikan rasa keadilan pada masyarakat, penyelesaian yang tidak tuntas dan bahkan seringkali menimbulkan masalah baru dalam masyarakat akibat putusan yang dianggap tidak sesuai dengan harapan masyarakat luas. Melalui penerapan keadilan restoratif dalam penyelesaian delik adat, maka kepentingan korban yang selama ini oleh peradilan formal diabaikan, menjadi lebih diperhatikan dalam pertemuan yang digelar oleh kedua belah pihak, dan dalam 
suasana kekeluargaan. Perdamaian yang ditempuh oleh para pihak semata-mata bertujuan untuk mencari keadilan dan memulihkan keadaan kembali seperti sediakala.

Desa Kedang Ipil merupakan salah satu desa tertua di Kecamatan Kota Bangun Kabupaten Kutai Kartanegara. Desa Kedang Ipil sudah ada sebelum Indonesia merdeka yaitu berdiri sejak 1917 dan Desa Kedang Ipil merupakan satu satunya desa di Kecamatan Kota Bangun yang mempunyai adat-istiadat dan budaya yang khas serta memiliki kekayaan objek wisata alam dan budaya. Sebagai salah satu desa yang masih menjunjung tinggi nilai-nilai adat dan budayanya, Desa Kedang Ipil pula masih melakukan upaya penyelesaian masalah yang terjadi di masyarakat dengan menggunakan perdailan adat. Salah satu masalah yang diselesaikan melalui peradilan adat di Desa Kedang Ipil adalah perzinahan. Berdasarkan perspektif norma adat terhadap perzinaan tersebut, penyelesaian delik perzinaan atau perselingkuhan di desa Kedang Ipil untuk Masyarakat Kutai Adat Lawas diselesaikan dengan menggunakan pidana adat yaitu jika pelaku perselingkuhan itu dalam keadaan tertangkap basah (sumbang) maka yang pihak yang menangkap tidak dibenarkan melakukan tindakan main hakim sendiri serta pihak yang menangkap hanya diperbolehkan untuk mengambil bukti atau tanda untuk dilaporkan berupa baju atau sejenisnya yang digunakan oleh pelaku.

Permasalahan yang akan dibahas dalam artikel ini adalah bagaimanakah penerapan restorative justice dalam tindak pidana perzinaan pada Masyarakat Kutai Adat Lawas.

\section{METODE PENELITIAN}

Penelitian ini dilakukan dengan metode sosiologis dimana hukum dikonsepkan sebagai pranatan sosial yang secara riil dikaitkan dengan variabel-varieabel sosial yang lain. ${ }^{1}$ Selain itu, jenis penelitian yang berorientasi pada aspek hukum dan aspek non hukum yakni mengkaji dan menganalisis bekerjanya hukum dalam masyarakat terkait dengan penerapan restorative justice dalam tindak pidana perzinaan pada Masyarakat Kutai Adat Lawas. Penelitian ini pula menitikberatkan pada perilaku individu atau masyarakat dalam kaitannya dengan hukum.

\section{PEMBAHASAN}

\section{Pengertian Pidana Adat}

Hukum pidana adat merupakan terjemahan dari istilah Belanda yaitu Adat Delicten recht atau hukum pelanggaran adat. Istilah tersebut tidak dikenal di kalangan masyarakat adat. Mereka menggunakan istilah lain seperti Salah (Lampung), Sumbang (Sumatera Selatan) untuk menyatakan yang bertentangan dengan hukum adat. Menurut Hilman Adi Kusuma, hukum pidana adat

\footnotetext{
${ }^{1}$ Djulaeka dan Devi Rahayu, Buku Ajar: Metode Penelitian Hukum, Scopindi Media Pustaka, Surabaya: 2019, hlm. 56.
} 
Penerapan Restorative Justice dalam Tindak Pidana Perzinaan pada Masyarakat Kutai Adat Lawas

merupakan hukum yang hidup (living law). Hukum pidana adat dijiwai oleh Pancasila, dijiwai oleh sifat-sifat kekeluargaan yang magis religius, di mana yang diutamakan bukanlah rasa keadilan perorangan melainkan rasa keadilan kekeluargaan sehingga cara penyelesaiannya adalah dengan penyelesaian damai yang membawa kerukunan, keselarasan dan kekeluargaan. Hukum pidana adat tidak bermaksud menunjukkan hukum dan hukuman apa yang harus dijatuhkan bila terjadi pelanggaran, namun yang menjadi tujuannya adalah memulihkan kembali yang pincang sebagai akibat terjadinya pelanggaran.

Selanjutnya Hazairin menyebutkan masyarakat hukum adat merupakan kesatuan-kesatuan kemasyarakatan yang mempunyai kelengkapan-kelengkapan untuk sanggup berdiri sendiri yaitu mempunyai kesatuan hukum, kesatuan penguasa dan kesatuan lingkungan hidup berdasarkan hak bersama atas tanah dan air bagi semua anggota.

Selain itu, menurut F. D Holleman yang sependapat dengan Van Vollenhoven mengartikan hukum adat adalah norma-norma yang hidup yang disertai dengan sanksi atau hukuman dan jika perlu dapat dipaksakan oleh masyarakat atau badan-badan yang bersangkutan agar ditaati dan dihormati oleh para warga masyarakat. Tidak ada masalah apakah norma-norma tersebut ada atau tidaknya keputusan petugas hukum. ${ }^{2}$

\section{Pengertian Zina}

Pengertian zina dalam dunia Barat diartikan sebagai persetubuhan yang dilakukan di mana salah satu pelaku atau kedua pelaku sudah terikat perkawinan dengan orang lain. Jadi jika persetubuhan tersebut dilakukan oleh orang yang sama-sama tidak terikat perkawinan maka tidak dapat dihukum sebagai perbuatan zina. Sedangkan menurut orang Islam, zina adalah melakukan hubungan kelamin antara seorang lelaki dengan seorang perempuan yang tidak terikat dalam status perkawinan, sehingga siapa pun yang telah melakukan persetubuhan dengan orang baik yang bukan suami atau istrinya maka dihukum zina. ${ }^{3}$

Pengertian zina menurut mazhab Maliki sebagaimana dikutip oleh Abdul Qadir Audah, zina adalah persetubuhan yang dilakukan oleh orang mukalaf terhadap farji manusia (wanita) yang bukan miliknya secara disepakati dengan kesengajaan.

Menurut Abdul Halim Hasan, zina artinya seorang laki-laki memasukkan kemaluannya ke dalam kemaluan perempuan, dengan tidak ada nikah dan terjadinya tidak pula dengan subhat. Pengertian ini hampir serupa dengan pengertian yang dikemukakan oleh Abdul Djamali, yakni zina

\footnotetext{
2 Maharaeni Ria Siombo dan Henny Wiludjeng, Hukum adat dalam Perkembangannya, Universitas Katolik Indonesia Atma Jaya, Jakarta: 2020, hlm. 6.

3 Syamsul Huda, "Zina dalam perspektif Hukum Islam dan Kitab Undang-undang Hukum Pidana".Journal Studia Islamika 12 (Februari) 2015, E-Journal on-line, <http://oaji.net/articles/2016/1163-1458782805.pdf>, [diakses pada 20/08/2020].
} 
adalah perbuatan memasukkan kemaluan laki-laki sampai katuknya ke dalam kemaluan perempuan yang diinginkan.

Zina merupakan tindak pidana yang diancam dengan hukuman ḥudūd atau had, yakni suatu hukuman yang diberlakukan terhadap pelanggaran yang menyangkut hak Allah. Dengan demikian, hukuman tindak pidana zina telah diatur oleh Alquran karena merupakan hak Allah SWT secara mutlak.

Pengertian zina menurut Kamus Besar Bahasa Indonesia adalah: 1. Perbuatan bersanggama antara laki-laki dan perempuan yang tidak terikat oleh hubungan pernikahan (perkawinan); 2 . Perbuatan bersenggama seorang laik-laki yang terkait perkawinan dengan seorang perempuan yang bukan istrinya, atau seorang perempuan yang terikat perkawinan dengan seorang laki-laki yang bukan suaminya ${ }^{4}$

Berdasarkan dengan beberapa pengertian zina di atas dapat disimpulkan perzinahan yaitu terjadinya persetubuan dan persetubuhan terjadi karena masuknya alat kelamin laki-laki ke dalam alat kelamin perempuan serta dilakukan tanpa ada ikatan perkawinan yang sah dan atas dasar suka sama suka. ${ }^{5}$

\section{Pengaturan Delik Perzinaan}

Dalam Kitab Undang-Undang Hukum Pidana (KUHP) perzinaan diatur dalam Pasal 284 KUHP, dirumuskan sebagai berikut:

“ayat (1) Diancam dengan pidana penjara selama-lamanya sembilan bulan:

1e. a. laki-laki yang beristri, berbuat zina, sedang diketahuinya, bahwa Pasal 27 Kitab Undang-Undang Hukum Perdata (sipil) berlaku baginya;

b. Perempuan yang bersuami, berbuat zina.

2e. a. laki-laki yang turut melakukan perbuatan itu, sedang diketahuinya, bahwa kawanannya itu bersuami.

b. Perempuan yang tiada bersuami yang turut melakukan perbuatan itu, sedang diketahuinya, bahwa kawanannya itu beristri dan Pasal 27 Kitab Undang-Undang Hukum Perdata (sipil) berlaku pada kawanannya itu."

ayat (2) Penuntutan hanya dilakukan atas pengaduan suami (istri) yang mendapat malu dan jika pada suami (istri) itu berlaku Pasal 27 Kitab Undang-Undang Hukum Perdata (sipil) dalam tempo 3 bulan sesudah pengaduan ini, diikuti dengan permintaan akan bercerai atau bercerai tempat tidur dan meja makan (scheiding van tafel en bed) oleh perbuatan itu juga.

\footnotetext{
${ }^{4}$ Tanpa nama, "Arti Kata Zina”, Kamus Besar Bahasa Indonesia (KBBI) online, (tanpa tahun), <https://kbbi.web.id/zina>, [diakses pada 30/01/2020].

5 La Jamaa, "Tantangan Modernitas Hukum Pidana Islam”, Ahkam: Jurnal Ilmu Syariah, Vol. 2, Juli 2016, hlm. 265.
} 
Penerapan Restorative Justice dalam Tindak Pidana Perzinaan pada Masyarakat Kutai Adat Lawas

ayat (3) tentang pengaduan ini Pasal 72,73 dan 75 tidak berlaku.

ayat (4) Pengaduan itu boleh dicabut selama pemeriksaan di muka sidang pengadilan belum dimulai.

ayat (5) kalau bagi suami istri itu berlaku Pasal 27 Kitab Udang-Undang Hukum Perdata (Sipil) maka pengaduan itu tidak diindahkan, sebelumnya mereka itu bercerai, atau sebelum keputusan hakim tentang perceraian tempat tidur dan meja makan mendapat ketetapan."

Penjelasan Pasal 284, menurut R. Soesilo, menyatakan zina adalah persetubuhan yang dilakukan oleh laki-laki atau perempuan yang telah kawin dengan perempuan atau laki-laki yang bukan istri atau suaminya. Supaya masuk pasal ini, maka persetubuhan itu harus dilakukan dengan suka sama suka, tidak boleh ada paksaan dari salah satu pihak, sedangkan yang dimaksud dengan persetubuhan ialah pengaduan antara anggota kemaluan laki-laki dan perempuan yang biasa dijalankan untuk mendapatkan anak, jadi anggota laki-laki harus masuk ke dalam anggota perempuan, sehingga mengeluarkan air mani, sesuai dengan Arrrest Hooge Raad 5 Februari 1912 (W.9292).

Oleh karena itu, jika merujuk pada ketentuan KUHP yang berlaku saat ini, terdapat 4 (empat syarat) agar seseorang dapat dinyatakan telah melakukan perbuatan zina, yaitu:

1. Melakukan persetubuhan dengan perempuan atau laki-laki bukan suami atau bukan istrinya. (orang ini tidak harus telah menikah)

2. Dirinya tidak tunduk pada Pasal 27 Kitab Undang-Undang Hukum Perdata (KUH Perdata)

3. Pasangannya yang melakukan persetubuhan itu tunduk pada Pasal 27 KUH Perdata

4. Diketahuinya bahwa pasangannya melakukan persetubuhan itu telah bersuami atau beristri, dan belaku ketentuan Pasal 27 KUH Perdata berlaku bagi pasangannya bersetubuh itu.

Selain itu, Pasal 284 KUHP merupakan delik aduan absolut dimana ada pihak yang dirugikan apakah pihak yang dirugikan tersebut seorang suami atau istri yang dikhianati melakukan pengaduan kepada penegak hukum dalam hal ini pihak yang berwajib (polisi) dan selama perkara itu belum diperiksa di muka pengadilan, maka pengaduan itu senantiasa dapat ditarik kembali. Selanjutnya Pasal 284 KUHP ini tidak bisa dikenakan terhadap kedua belah pihak yang belum terikat dalam perkawinan.

Perzinaan dalam Rancangan Kitab Undang-Undang Hukum Pidana 2019 (R KUHP 2019) mengalami perluasan makna dalam rumusan deliknya. Dalam R KUHP 2019, tindak pidana zina diatur dalam Pasal 417 ayat (1) sampai dengan ayat (4) yaitu sebagai berikut:

1. Setiap orang yang melakukan persetubuhan dengan orang yang bukan suami atau istrinya dipidana karena perzinaan dengan pidana penjara paling lama 1 (satu) tahun atau denda kategori II. 
2. Tindak pidana sebagaimana dimaksud pada ayat (1) tidak dilakukan penuntutan kecuali atas pengaduan suami, istri, orang tua, atau anaknya

3. Terhadap pengaduan sebagaimana dimaksud pada ayat (2) tidak berlaku ketentuan sebagaimana dimaksud dalam Pasal 25, Pasal 26 dan Pasal 30

4. Pengaduan dapat ditarik kembali selama pemeriksaan di sidang pengadilan belum dimulai.

Pasal 418 ayat (1) sampai dengan ayat (5) sebagai berikut:

1. Setiap orang yang melakukan hidup bersama sebagai suami istri di luar perkawinan dipidana dengan pidana penjara paling lama 6 (enam) bulan atau pidana denda paling banyak kategori II;

2. Tindak pidana sebagaimana dimaksud pada ayat (1) tidak dilakukan penuntutan kecuali atas pengaduan suami, istri, orang tua atau anaknya;

3. Pengaduan sebagaimana dimaksud pada ayat (2) dapat juga diajukan keberatan dari suami, istri, orang tua, atau anaknya;

4. Terhadap pengaduan sebagaimana dimaksud pada ayat (2) tidak berlaku ketentuan Pasal 25 , Pasal 26, dan Pasal 30.

5. Pengaduan dapat ditarik kembali selama pemeriksaan di sidang pengadilan belum mulai.

Pasal 419 menyatakan: setiap orang yang melakukan persetubuhan dengan seseorang yang diketahuinya bahwa orang tersebut merupakan anggota keluarga sedarah dalam garis lurus atau ke samping sampai derajat ketiga dipidana dengan pidana penjara paling lama 12 (dua belas) tahun.

Pasal 25 Rancangan KUHP September 2019 yaitu:

1. Dalam hal korban tindak pidana aduan belum berusia 16 (enam belas) tahun, yang berhak mengadu merupakan orang tua atau walinya;

2. Dalam hal orang tua atau wali sebagaimana dimaksud Ayat (1) tidak ada atau orang tua atau wali itu sendiri yang harus diadukan, pengaduan dilakukan oleh keluarga sedarah dalam garis lurus.

3. Dalam hal keluarga sedarah dalam garis lurus sebagaimana dimaksud pada Ayat (2) tidak ada, pengaduan dilakukan oleh keluarga sedarah dalam garis menyamping sampai derajat ketiga.

4. Dalam hal anak tidak memiliki orang tua, wali, atau sekeluarga sedarah dalam garis lurus ke atas ataupun menyimpang sampai derajat ketiga, pengaduan dilakukan oleh diri sendiri dan/atau pendamping.

Sedangkan Pasal 26 Rancangan KUHP September 2019 yaitu:

1. Dalam hal korban tindak pidana aduan berada di bawah pengampuan, yang berhak mengadu merupakan pengampunya, kecuali bagi korban tindak pidana aduan yang berada dalam pengampuan karena boros. 
2. Dalam hal pengampu sebagaimana dimaksud pada ayat (1) tidak ada atau pengampu itu sendiri yang harus diadukan, pengaduan dilakukan oleh suami atau istri korban atau keluarga sedarah dalam garis lurus.

3. Dalam hal suami atau istri korban atau keluarga sedarah dalam garis lurus sebagaimana dimaksud pada ayat (2) tidak ada, pengaduan dilakukan oleh keluarga sedarah dalam garis menyamping sampai derajat ketiga.

Selanjutnya Pasal 27 Rancangan KUHP September 2019 yaitu: dalam hal korban tindak pidana aduan meninggal dunia, pengaduan dapat dilakukan oleh orang tua, anak, suami, atau istri korban, kecuali jika korban sebelumnya secara tegas tidak menghendaki adanya penuntutan.

\section{Perspektif Hukum Islam}

Para ulama memiliki berbagai definisi tentang zina, diantaranya:

1. Mahzab Malikiyah, zina diartikan perbuatan mukalaf yang menyetubuhi farji anak adam yang bukan miliknya secara sepakat (tanpa adanya syubhat) dan disengaja

2. Mahzab Hanafiyah, zina adalah nama bagi persetubuhan yang haram dalam qubul (kelamin) seorang perempuan yang masih hidup dalam keadaan ikhitiar (tanpa paksaan) di dalam negeri yang adil yang dilakukan oleh orang-orang kepadanya berlaku hukum Islam, dan wanita tersebut bukan miliknya dan tidak ada syubhat dalam miliknya.

3. Mahzab Syafi'iyyah, zina adalah memasukkan zakar ke dalam farji yang diharamkan karena zatnya tanpa adanya syubhat dan menurut tabiatnya menimbulkan syahwat.

4. Mahzab Habilah, zina adalah melakukan perbuatan keji (perbuatan), baik terhadap qubul (farji) maupun dubur.

5. Pendapat Imamiyah, zina adalah masuknya penis terhadap farji perempuan yang haram baik melalui depan (vagina) atau belakang (anus), tidak terikat akad nikah, bukan miliknya, dan tidak ada syubhat. $^{6}$

Selanjutnya, zina merupakan perbuatan yang dilarang dalam hukum Islam, termasuk juga segala hal yang menghantarkan pada tindakan zina, sebagaimana disebutkan dalam Al Qur'an surat Al-Isra, ayat 32, yaitu: "Dan janganlah kamu mendekati zina, sesungguhnya zina itu adalah perbuatan yang keji dan suatu jalan yang buruk."

Hukum Islam mengelompokkan pelaku zina menjadi dua macam untuk menetapkan jenis hukuman yang akan dilaksanakan, yaitu: ${ }^{7}$

\footnotetext{
${ }^{6}$ Mia Amalia, "Prostitusi dan Perizinan dalam Perspektif Hukum Islam". Tahkim Journal Peradaban dan Hukum Islam 01 (Januari) 2018, E-Journal on-line, <https://ejournal.unisba.ac.id/index.php/tahkim/article/view/3265>, [diakses pada 30/01/2020].

7 Abdul Manan, Penerapan Hukum Acara Perdata di Lingkungan Peradilan Agama Edisi 2, Kencana, Jakarta: 2016, hlm. 474.
} 
1. Zina Muhsan, yaitu zina yang dilakukan oleh orang yang telah baliq, berakal, meredak dan telah menikah, baik masih terikat perkawinan maupun yang telah bercerai atau dengan kata lain zina muhsan dilakukan oleh orang yang pernah menikah dan hukuman yang dikenakan baginya adalah dirajam sampai mati.

Pendapat ini didasarkan atas hadist Rasulullah SAW yaitu:

Artinya: "Abu Hurairah dan Jabir ra., Abu Hurairah berkata: "Ada seorang pria datang kepada Rasulullah SAW., ketika beliau sedang berada di masjid, hingga beliau memanggilnya, maka ia berkata: "Ya Rasulullah, saya telah berzina". (Mendengar ucapan itu) Rasulullah berpaling darinya, tetapi orang itu mengulang-ngulang perkataannya sebanyak empat kali. Tatkala ia mengakui akan dirinya (yang berzina itu), maka Nabi SAW memanggilnya seraya berkata: “Apakah engkau ini gila?" ia menjawab: "Ya (benar)". Kemudian Nabi SAW bersabda: "Bawalah orang ini, kemudian kenakanlah hukuman rajam!" (HR. Bukhari dan Muslim).

2. Zina Ghairu Muhsan, yaitu perbuatan zina yang dilakukan oleh laki-laki dengan wanita yang tidak ada ikatan perkawinan antara keduanya. Hukuman bagi pelakunya adalah hukuman jilid atau cambuk sebanyak 100 kali.

Dalam Al Qur'an Surat An-Nur ayat 1-2 berbunyi: “(Ini adalah) satu surah yang kami turunkan dan Kami wajibkan (menjalankan hukum-hukum yang ada didalam)nya, dan kami turunkan di dalamnya ayat-ayat yang jelas, agar kamu selalu mengingatinya. Perempuan yang berzina dan laki-laki yang berzina, maka deralah tiap-tiap seorang dari keduanya seratus kali cambukan, dan janganlah belas kasihan kepada keduanya mencegah kamu untuk (menjalankan) agama Allah, jika kamu beriman kepada Allah dan hari kiamat, dan hendaklah (pelaksanaan) hukuman mereka disaksikan oleh sekumpulan orang-orang yang beriman." (Q.S. An Nuur 1-2).

Selanjutnya dalam ayat tersebut menjelaskan wanita penzinaan dan laki-laki sama-sama didera dengan 100 kali cambukan. Ini berlaku bagi penzinaan yang masih bujang. Namun, bagi yang telah menikah, maka dikenai hukuman raja sebagaimana kisah wanita Juhainah dalah hadist berikut ini: ${ }^{8}$

"Ada seorang wanita dari Bani Juhainah mendatangi Rasulullah shallallahu 'alaihi wa sallam sedangkan ia dalam keadaan hamil karena zina. Wanita ini lalu berkata kepada Rasulullah shallallahu 'alaihi wa sallam, "Ya Rasulullah, aku telah melakukan sesuatu yang berbuatan

\footnotetext{
8 Muhammad Abduh Tuasikal dan MSc, “"Faedah Surat An-Nuur \#01: Hukuman Bagi Pezina dan Peselingkuh” Rumaysho.Com., (tanpa tahun), <https://rumaysho.com/16274-faedah-surat-an-nuur-01-hukuman-bagi-pezina-dan-peselingkuh.html>, [diakses pada 20/08/2019].
} 
Penerapan Restorative Justice dalam Tindak Pidana Perzinaan pada Masyarakat Kutai Adat Lawas

tersebut layak mendapatkan hukuman raja. Laksanakanlah hukuman hadd atas diriku. "Nabi shallallahu 'alaihi wa sallam lantas memanggil wali wanita tersebut, lalu beliau berkata pada walinya, "Berbuat baiklah pada wanita ini dan apabila ia telah melahirkan (kandungannya), maka datanglah padaku (dengan membawa dirinya)."

Wanita tersebut pun menjalankan apa yang diperintahkan oleh Rasulullah shallallahu 'alaihi wa sallam. Setelah itu, beliau meminta wanita tersebut dipanggil, lalu diikat pakaiannya dengan erat (agar tidak terbuka auratnya ketika menjalani hukuman rajam, pen). Kemudian saat itu diperintah untuk dilaksanakan hukuman rajam. Wanita itu pun meninggal dunia, lantas beliau pun menyolatkannya. Ketika itu, 'Umur berkomentar pada Nabi shallallahu 'alaihi wa sallam, "Engkau menyolatkan dirinya, wahai Nabi Allah, padahal dia telah berbuat zina? "Beliau bersabda, Wanita ini telah bertaubat dengan taubat yang seandainya taubatnya tersebut dibagi kepada 70 orang dari penduduk Madinah maka itu bisa mencukupi mereka. Apakah engkau dapati taubat yang lebih baik dari seseorang mengorbankan jiwanya karena Allah Ta'ala?" (HR. Muslim, no. 1696).

Ditambah dalam hadist selain dikenakan 100 kali cambukan, nantinya akan diasingkan. Dari 'Ubadah bin Ash-Shamit radhiyallahu' anhu, Nabi shallallahu'alaihi wa sallam bersabda: "Ambillah dariku, ambillah dariku! Allah telah menjadikan bagi mereka jalan keluar. (Apabila berzina) jejaka dengan gadis (maka haddnya) dicambuk seratus kali dan diasingkan setahun. (Apabila berzina) dua orang yang sudah menikah (maka hadd-nya) dicambuk seratus kali dan dirajam.' (HR. Muslim no. 1690).

Menurut Masjfuk Zuhdi dalam Ni'matul, Khoiriyah menyatakan unsur-unsur zina menurut hukum pidana Islam adalah sebagai berikut: ${ }^{9}$

1. Persetubuhan yang diharamkan (sexual intercourse) antara dua orang yang berbeda jenis kelaminnya (heterosex); dan

2. Tidak adanya keserupaan atau kekeliruan (syubhat) dalam perbuatan seks (sex act).

Penjelasan unsur-unsur zina menurut hukum pidana Islam sebagai berikut:

1. Persetubuhan yang dianggap sebagai zina adalah persetubuhan dalam farji (kemaluan). Di samping itu, kaidah untuk menentukan persetubuhan sebagai zina adalah persetubuhan terjadi bukan pada miliknya sendiri.

2. Unsur kedua (syubhat), maka sexual intercourse yang dilakukan oleh orang karena kekeliruan, misalnya dikira "istrinya", juga tidak dapat disebut zina.

\footnotetext{
9 Ni'matul, Khoiriyah, Sanksi bagi pelaku perzinaan dalam Pasal 284 KUHP:Perspektif Hukum Pidana Islam. Diploma thesis, UIN Sunan Gunung Djati Bandung, http://digilib.uinsgd.ac.id/8086/6/6_Bab\%203.pdf, [diakses pada 23/08/2019].
} 
Tindak Pidana Perzinaan Berdasarkan Hukum Pidana Adat pada Masyarakat Kutai Adat lawas di Desa Kedang Ipil Kabupaten Kutai Kartanegara Kalimantan Timur.

Konflik merupakan suatu keadaan yang timbul sebagai akibat dari terganggunya hubungan antara dua pihak. Masing-masing pihak merasa benar dan tidak mengakui kelemahannya, dan berupaya untuk mempertahankan kehendaknya. Konflik dapat dipandang dari aspek positif dan negatif. Dari aspek positif karena adanya konflik, maka ada upaya untuk mempersatukan adanya perbedaan yang terjadi melalui mekanisme yang disepakati. Dari aspek negatifnya bahwa konflik menyebabkan hubungan yang awalnya baik dan harmonis, maka menjadi retak dan tidak harmonis lagi, dan hilang suasana keakrabannya. ${ }^{10}$

Pada umumnya masyarakat berpandangan bahwa sengketa (konflik) hanya bisa diselesaikan melalui jalur Pengadilan, bahkan sebagian besar kalangan profesional hukum pun berpandangan yang sama. Sampai saat ini banyak dari kalangan mereka hanya terpaku memilih jalur litigasi dan melupakan serta mengabaikan cara-cara penyelesaian sengketa melalui jalur non-litigasi misalnya melalui Alternatif Penyelesaian Sengketa (ADR). Sebagaimana dikutip dalam bukunya I Made Widnyana, bahwa Dispute Resolution yang biasa disebut "Alternative Dispute Resolution" adalah serangkaian proses yang bertujuan untuk menyelesaikan sengketa antara pihak-pihak. ${ }^{11}$

Menurut Randall Collins, konflik adalah proses sentral dalam kehidupan sosial. Jadi, dalam kehidupan sosial/bermasyarakat tentunya pasti akan selalu timbul konflik. Sebetulnya, konflik dapat berimplikasi positif, yakni, dapat membantu individu-individu/kelompok-kelompok yang berkonflik tersebut menjadi lebih erat hubungannya. Hal tersebut dapat menciptakan kohesi sosial yang dapat mendorong terbentuknya stabilitas nasional. Akan tetapi, dalam realitasnya, sisi positif tersebut jarang terjadi, justru sisi negatif dari konflik, seperti terjadinya disintegrasi yang sering muncul. Di dalam masyarakat tradisional (adat), konflik yang timbul biasanya diselesaikan dengan cara-cara perdamaian. Hal ini dilakukan untuk mencegah terjadinya permusuhan, pertikaian, perpecahan (disintegrasi), dan sebagainya. Dalam menyelesaikan suatu konflik masing-masing individu/kelompok memiliki caranya masing-masing.

Menurut Nader dan Todd, ada beberapa cara/tahapan yang biasa dilakukan seseorang dalam menyelesaikan konflik/sengketa yang dihadapinya, yaitu:

1. Membiarkan saja (lumping it) Dalam tahapan ini, pihak yang merasa diperlakukan tidak adil/ dirugikan gagal dalam upaya menekan tuntutannya.

\footnotetext{
${ }^{10}$ Peter Bang, Papua Berdarah: Kesaksian seorang fotografer di Papua Barat yang lebih dari 30 tahun, BOD- Book on Demand, Jerman: $2018, \mathrm{hlm} .6$.

${ }^{11} \mathrm{lbid} ., \mathrm{hlm} .11$
} 
Penerapan Restorative Justice dalam Tindak Pidana Perzinaan pada Masyarakat Kutai Adat Lawas

2. Mengelak (avoidance). Pada tahapan ini, pihak yang merasa dirugikan memilih untuk mengurangi hubungan-hubungan dengan pihak yang merugikannya atau untuk sama sekali menghentikan hubungan tersebut.

3. Paksaan (coersion). Tahapan selanjutnya, yaitu paksaan (coersion) di mana salah satu pihak memaksakan pemecahan kepada pihak lain. Ini bersifat unilateral. Tindakan yang bersifat memaksakan ini atau ancaman untuk menggunakan kekerasan, pada umumnya mengurangi kemungkinan penyelesaian secara damai.

4. Perundingan (negotiation). Pada tahapan perundingan, dua pihak yang berhadapan merupakan para pengambil keputusan. Pemecahan dari permasalahan yang mereka hadapi dilakukan oleh mereka berdua, mereka sepakat, tanpa adanya pihak ketiga yang mencampuri.

5. Mediasi (mediation). Dalam cara ini, ada pihak ketiga yang membantiu kedua pihak yang berselisih pendapat untuk menemukan kesepakatan. Pihak ketiga ini dapat ditentukan oleh kedua belah pihak yang bersengketa atau ditunjukkan oleh yang berwenang untuk itu.

6. Arbitrage. Kedua belah pihak yang bersengketa sepakat untuk meminta perantara pihak ketiga, arbitrator, dan sejak semula telah setuju bahwa mereka akan menerima keputusan dari arbitrator itu.

7. Peradilan (adjudication). Di sini, pihak ketiga mempunyai wewenang untuk mencampuri pemecahan masalah, lepas dari keinginan para pihak bersengketa. Pihak ketiga itu juga berhak membuat dan menegakkan keputusan itu artinya bahwa keputusan berupaya dilaksanakan.

Merujuk pada pendapat Nader dan Todd tersebut, dapat diketahui bahwa penyelesaian tindak pidana perzinahan pada masyarakat adat lawas di Desa Kedang Ipil ditempuh dengan menggunakan konsep keadilan restoratif (restorative justice). Penerapan keadilan restoratif ini nampak ketika penyelesaian tersebut melibatkan pelaku dan korban sebagai pihak yang berkompeten dalam perkara tersebut. Para pihak berupaya untuk melakukan dialog dan melakukan pertemuan untuk menyelesaikan secara musyawarah dan mufakat sehingga tercapai kesepakatan.

Penyelesaian tindak pidana adat pada masing-masing masyarakat hukum adat beragam. Mekanisme dan cara yang dilakukan, tetapi pada umumnya memiliki tujuan yang sama yaitu untuk mengembalikan keadaan semula tanpa adanya pihak yang merasa keberatan sehingga menciptakan kembali keadaan keharmonisan dan keserasian dalam kehidupan masyarakat. Adapun penerapan keadilan restoratif terlihat dalam mekanisme penyelesaian tindak pidana perzinahan pada masyarakat adat lawas di Desa Kedang Ipil, yaitu:

Penyelesaian delik perzinaan atau perselingkuhan di desa Kedang Ipil untuk Masyarakat Kutai Adat Lawas diselesaikan dengan menggunakan pidana adat yaitu jika pelaku perselingkuhan itu tertangkap basah (sumbang) maka yang menangkap tidak boleh main hakim sendiri dan yang 
menangkup hanya perlu mengambil bukti atau tanda untuk dilaporkan. Bukti tersebut berupa baju atau sejenisnya yang digunakan oleh pelaku. ${ }^{12}$

Dalam hal pelaporan dapat dilakukan dengan membawa barang bukti ke Rukun Tetangga (RT) atau orang yang dituakan atau yang dapat mengurusi permasalahan tersebut dan orang yang diminta tolong tersebut adalah orang yang tidak memiliki hubungan darah dengan pelapor. Pengurusan dilakukan paling lama 1 (satu) bulan agar permasalahan tidak bertambah besar. Selanjutnya, pihak yang dimintai tolong menyerahkan segala hasil penyelidikan kepada lembaga adat untuk diproses. Pihak lembaga adat kemudian membuka persidangan yang dihadiri seluruh penduduk di desa Kedang Ipil.

Proses persidangan untuk delik perzinaan yaitu pada saat sidang dibuka pertama-tama, pihak lembaga adat menceritakan mulai awal ditemukan atau menangkap basah pelaku sampai proses sidang, setelah kronologis kejadian telah selesai diceritakan selanjutnya sidang dikembalikan oleh lembaga adat. Di lembaga adat, para tokoh melemparkan kepada hadirin yang kemungkinan memiliki petunjuk lain atas kasus tersebut. Setelah selesai tokoh-tokoh adat memberikan putusan berupa denda yang terbagi dua yaitu; pertama, denda pelanggaran sejumlah Rp. 80.000 (delapan puluh ribu rupiah) yang akan diserahkan kepada lembaga adat sebagai pengganti uang sidang. Kedua, denda sejumlah Rp 500.000; (lima ratus ribu rupiah) yang diserahkan kepada korban (dalam hal ini pasangan yang dikhianati). Setelah menjatuhkan denda dan setelah selesai melakukan sidang pihak lembaga adat mengeluarkan nasihat yang dinamakan dengan gawai 100 (seratus) yang berisi:

“ Kalau kita langkahi

Api beryala

Kalau kita nyrudut berarti nyrunduk pondong bergantung

Ibarat serapang ujung batang. "

Artinya:

Kalau kita tidak peduli dengan orang tua, dapat menimbulkan permasalahan bagi kita.

Kalau kita tetap melakukan kesalahan.

Begitu muncul atau terkuak kesalahan tersebut akan disidang atau diproses dan dikenai denda.

Berdasarkan gawai 100 (seratus) tersebut, para pelaku jika mengulang kembali harus membayar denda dua kali lipat dari sebelumnya.

Selanjutnya delik perzinaan di Desa kedang Ipil dalam hal denda adat sumbang (tertangkap basah) terhadap pelaku perzinaan terbagi menjadi 4 (empat) yaitu:

\footnotetext{
${ }^{12}$ Wawancara dengan Bapak Sartin selaku penggiat kebudayaan di Desa Kedang Ipil, tanggal 25 Juni 2019.
} 
Penerapan Restorative Justice dalam Tindak Pidana Perzinaan pada Masyarakat Kutai Adat Lawas

1. Muda mudi lajang atau dengan kata lain kedua duanya belum menikah (sama-sama lajang) Adat sumbang ini biasanya sesuai dengan adat istiadat Kutai Adat Lawas sejumlah Rp 500.000 (lima ratus ribu rupiah) laki-laki, Rp 500.000 (lima ratus ribu rupiah) perempuan ditambah dengan denda pelanggaran norma adat sejumlah $\mathrm{Rp} 80.000$ (delapan puluh ribu rupiah) terhadap muda mudi. Jadi total keseluruhan denda adat sejumlah Rp 1.160.000 (satu juta seratus enam puluh ribu rupiah) dan seluruh denda ini diberikan kepada lembaga adat. Keseluruhan denda adat tersebut diberikan kepada lembaga adat jika kedua pelaku tidak mau atau menolak untuk dinikahkan, tetapi jika kedua muda mudi yang melakukan perzinaan tidak menolak untuk dinikahkan maka tidak dikenakan denda adat sumbang tetapi lembaga adat hanya meminta kepada muda mudi tersebut menyiapkan biaya pernikahan saja ditambah adat krama (jujuran) sejumlah Rp 600.000 (enam ratus ribu rupiah). Adat krama (jujuran) tersebut hanya dijatuhkan kepada laki-laki saja dan uang tersebut diberikan kepada perempuan sebagai cendera mata pada waktu wejangan pasangan pengantin, tetapi denda pelanggaran terhadap norma adat istiadat sejumlah Rp 80.000 (delapan puluh ribu rupiah) yang dijatuhkan kepada kedua muda mudi tersebut tetap diberikan kepada lembaga adat. Pernikahan ini biasanya, kedua mempelai diarak seperti pernikahan biasa atau seperti pasangan atas kemauan sendiri.

2. Laki-laki atau perempuan lajang dengan orang yang sudah berkeluarga (salah satu telah menikah) Adat sumbang antara laki-laki atau perempuan lajang dengan yang sudah berkeluarga sesuai dengan adat suku Kutai Adat Lawas sejumlah Rp 500.000 (lima ratus ribu rupiah) kepada laki-laki dan Rp 500.000 (lima ratus ribu rupiah) kepada perempuan ditambah denda pelanggaran terhadap norma adat istiadat sejumlah Rp 80.000 (delapan puluh ribu rupiah) untuk kedua pelaku. Selanjutnya pemberian denda adat sumbang tersebut yaitu denda sejumlah Rp 500.000 (lima ratus ribu rupiah) diberikan kepada suami atau istri dari pelaku perzinaan atau pasangan yang telah dikhianati dan denda sejumlah Rp 500.000 (lima ratus ribu rupiah) ditambah denda pelanggaran norma adat sejumlah Rp 160.000 (seratus enam puluh ribu rupiah) diberikan kepada lembaga adat. Denda tersebut akan dikenakan jika pelaku perzinahan mau dipisahkan dan tidak bersikeras untuk melanjutkan hubungan, tetapi jika pasangan pelaku perzinahan tersebut bersikeras ingin melanjutkan hubungan sampai ke jenjang pernikahan maka akan dikenakan denda adat perebutan sejumlah Rp 1.600 .000 (satu juta enam ratus ribu rupiah) laki-laki dan sejumlah Rp 1.600 .000 (satu juta enam ratus ribu rupiah) perempuan ditambah denda pelanggaran norma adat sejumlah Rp 80.000 (delapan puluh ribu rupiah) kepada kedua pelaku, mempersiapkan biaya pernikahan dan membayar denda adat krama (jujuran) sejumlah Rp 600.000 (enam ratus ribu rupiah). Selanjutnya, denda adat perebutan sejumlah Rp 1.600 .000 (satu juta enam ratus ribu rupiah) diberikan kepada suami atau istri yang akan diceraikan dan 
denda adat perebutan sejumlah Rp 1.600 .000 (satu juta enam ratus ribu rupiah) ditambah dengan denda pelanggaran terhadap norma adat istiadat sejumlah Rp 160.000 (seratus enam puluh ribu rupiah) diberikan kepada lembaga adat. Pernikahan ini biasanya kedua mempelai diarak seperti pernikahan biasa atau seperti pernikahan pasangan atas kemauan sendiri.

3. Laki-laki atau perempuan yang sama-sama berkeluarga (sama sudah menikah). Ada sumbang laki-laki atau perempuan yang sama-sama telah terikat dalam suatu ikatan pernikahan (sudah berkeluarga) sesuai dengan adat istiadat suku Kutai Adat Lawas sejumlah Rp 500.000 (lima ratus ribu rupiah) kepada laki-laki, sejumlah Rp 500.000 (lima ratus ribu rupiah) kepada perempuan ditambah denda pelanggaran norma adat istiadat sejumlah $\mathrm{Rp} 160.000$ (seratus enam puluh ribu) kepada kedua pelaku. Pemberian denda tersebut yaitu denda adat sumbang laki-laki diberikan kepada suami dari perempuan yang telah diselingkuhinya dan denda adat sumbang perempuan diberikan kepada istri laki-laki yang telah diselingkuhinya. Sedangkan denda pelanggaran norma adat istiadat diberikan kepada lembaga adat. Denda ini diberikan apabila kedua pelaku perzinaan tersebut tidak bersikeras untuk melanjutkan hubungan ke jenjang pernikahan. Selanjutnya, jika kedua pelaku perzinaan bersikeras ingin melanjutkan hubungan mereka ke jenjang pernikahan maka akan dikenakan denda adat perebutan sejumlah Rp 1.600.000 (satu juta enam ratus ribu rupiah) kepada laki-laki dan sejumlah Rp 1.600 .000 (satu juta enam ratus ribu rupiah) kepada perempuan ditambah denda pelanggaran norma adat istiadat sejumlah Rp 160.000; (seratus enam puluh ribu rupiah) kepada kedua pelaku ditambah biaya pernikahan dan adat krama (jujuran) sejumlah Rp 600.000 (enam ratus ribu rupiah). Denda adat perebutan laki-laki diberikan kepada suami yang diselingkuhi dan denda adat perebutan perempuan diberikan kepada istri laki-laki yang diselingkuhinya, selanjutnya untuk denda pelanggaran norma adat istiadat diberikan kepada lembaga adat. Pernikahan kedua pelaku perzinaan ini biasanya pengantin tidak diarak

4. Laki-laki atau perempuan yang sama-sama sudah pernah menikah (duda atau janda).

Adat sumbang pasangan perzinaan ini sama seperti adat sumbang pasangan muda-mudi jika pasangan ini menolak untuk dinikahkan tetapi jika pasangan ini tidak menolak untuk dinikahkan maka pengantinya tidak diarak seperti pasangan mudi-mudi atau sama-sama lajang.

Jika kejadian perselingkuhan tersebut terjadi lagi selama 3 (tiga) kali dan yang melakukan adalah orang yang sama maka akan diserahkan ke hukum positif yaitu hukum pidana.

\section{Penyelesaian Tindak Pidana dengan Menggunakan Hukum Adat}

Hukum pidana adat dapat dikatakan sebagai penyeimbang hukum positif karena sumber hukum pidana Indonesia bukan hanya pidana tertulis tetapi juga pidana tidak tertulis. Secara formal, 
Penerapan Restorative Justice dalam Tindak Pidana Perzinaan pada Masyarakat Kutai Adat Lawas

ketika Belanda memberlakukan Wetboek Strafrecht voor Nederlandh Indoe (1 Januari 1918), hukum pidana adat memang tidak diberlakukan tetapi secara materiil tetap berlaku dan diterapkan dalam praktik peradilan dan setelah kemerdekaan, pidana adat mendapat tempat lewat Undang-udang darurat Nomor 1 Drt 1951. Pasal 5 ayat (3) huruf b Undang-Undang ini menjelaskan tentang pidana adat yang tidak ada bandingannya dalam KUHP, pidana adat yang ada bandingannya dalam KUHP, dan sanksi adat. Sanksi adat dapat dijadikan pidana pokok atau pidana utama oleh hakim dalam memeriksa dan mengadili perbuatan yang menurut hukum yang hidup dianggap sebagai tindak pidana yang tidak ada bandingannya dalam KUHP. ${ }^{13}$

Selanjutnya, dalam perkara yang diputus Pengadilan Negeri Palu tahun 2010, majelis hakim mempertimbangkan bahwa pengertian zina tak semata-mata adalah dalam KUHP, tetapi juga 'makna menurut hukum adat'. Pertimbangan hakim merujuk pada yurisprudensi Mahkamah Agung Nomor $93 \mathrm{~K} / \mathrm{Kr} / 1975$, yang intinya menyebutkan delik zina adalah perbuatan terlarang lepas dari apakah perbuatan itu dilakukan di tempat umum atau tidak, lepas dari apakah salah satu pihak sudah menikah atau belum sesuai syarat Pasal 284 KUHP.

Putusan lain yang dikutip adalah putusan MA Nomor 1644K/Pid/1988 tanggal 15 Mei 1991. Dalam putusan ini majelis mempertimbangkan seseorang yang telah melakukan perbuatan yang menurut hukum yang hidup (hukum adat) di daerah tersebut merupakan suatu perbuatan yang melanggar hukum adat yaitu, delik adat. Kepala dan para pemuka adat memberi reaksi adat (sanksi adat) terhadap si pelaku tersebut. Sanksi adat itu telah dilaksanakan oleh terhukum. Terhadap si terhukum yang sudah dijatuhi 'reaksi adat' oleh kepala adat tersebut, maka ia tidak dapat diajukan lagi (untuk kedua kalinya) sebagai terdakwa dalam persidangan badan peradilan negara (Pengadilan Negeri) dengan dakwaan yang sama, melanggar hukum adat, dan dijatuhi penjara menurut KUHP (Pasal 5 ayat (3) huruf b Undang-Undang Darurat Nomor 1 Drt 1951). Dalam keadaan yang demikian itu, maka pelimpahan berkas perkara serta tuntutan kejaksaan di Pengadilan Negeri harus dinyatakan tidak dapat diterima (niet ontvankelijk verklaard) .

Pasal 5 ayat (3) sub b Undang-Undang Darurat Nomor 1 Tahun 1951 (LN 1951 Nomor 9) sebagaimana disebutkan bahwa:

"hukum materiil sipil dan untuk sementara waktupun hukum materiil pidana sipil yang sampai kini berlaku untuk kaula-kaula daerah swapraja dan orang-orang yang dahulu diadili oleh pengadilan adat, ada tetap berlaku untuk kaula-kaula dan orang itu dengan pengertian bahwa suatu perbuatan yang menurut hukum yang hidup harus dianggap perbuatan pidana, akan tetapi tiada bandingnya dalam Kitab Hukum Pidana Sipil, maka dianggap diancam dengan

\footnotetext{
${ }^{13}$ Mys, "Putusan-putusan yang Menghargai Pidana Adat", (tanpa tahun), <https://www.hukumonline.com/berita/baca/ It5746f66360762/putusan-putusan-yang-menghargai-pidana-adat/>, [diakses pada 22/08/2018]
} 
hukuman yang tidak lebih dari tiga bulan penjara dan/atau denda lima ratus rupiah, yaitu sebagai hukuman pengganti bilamana hukuman adat yang dijatuhkan tidak diikuti oleh pihak yang terhukum dan penggantian yang dimaksud dianggap sepadan oleh hakim dengan besar kesalahan terhukum, bahwa bilamana hukum adat yang dijatuhkan itu menurut pikiran hakim melampaui padanya dengan hukuman kurungan atau denda yang dimaksud di atas, maka atas kesalahan terdakwa dapat dikenakan hukuman pengganti setinggi 10 tahun penjara, dengan pengertian bahwa hukuman adat yang menurut paham hakim tidak selaras lagi jaman senantiasa diganti seperti tersebut di atas, bahwa suatu perbuatan yang menurut hukum yang hidup harus dianggap perbuatan pidana yang ada bandingnya dalam Kitab Undang-Undang Hukum Pidana Sipil, maka dianggap diancam dengan hukuman sama dengan hukuman bandingnya yang paling mirip kepada perbuatan pidana tersebut."

Ada 3 (tiga) kesimpulan yang dapat dijadikan dasar dari ketentuan Pasal 5 ayat (3) sub b Undang-Undang Darurat Nomor 1 Tahun 1951 yaitu: ${ }^{14}$

1. Bahwa tindak pidana adat yang tiada bandingan atau padanan dalam KUHP di mana sifatnya tidak berat atau dianggap tindak pidana adat yang ringan ancaman pidananya adalah pidana penjara dengan ancaman paling lama tiga bulan dan/atau denda sebanyak lima ratus rupiah (setara dengan kejahatan ringan), minimumnya sebagaimana termaktub dalam ketentuan Pasal 12 KUHP yaitu 1 (satu) hari untuk pidana penjara dan pidana denda minimal 25 sen sesuai dengan ketentuan Pasal 30 KUHP. Akan tetapi, untuk tindak pidana adat yang berat ancaman pidana paling lama 10 (sepuluh) tahun, sebagaimana pengganti hukum adat yang tidak dijalani oleh terdakwa;

2. Tindak pidana adat yang ada bandingnya dalam KUHP maka ancaman pidananya sama dengan ancaman pidana yang ada dalam KUHP seperti misalnya tindak pidana adat Drati Kerama di Bali atau Mapangaddi (Bugis), Zina (Makasar) yang sebanding dengan tindak pidana zina sebagaimana dalam ketentuan Pasal 284 KUHP;

3. Sanksi adat sebagaimana ketentuan konteks di atas dapat dijadikan pidana pokok atau pidana utama oleh hakim dalam memeriksa, mengadili dan memutus perbuatan yang menurut hukum yang hidup (living law) dianggap sebagai tindak pidana yang tiada bandingnya dalam KUHP sedangkan tindak pidana yang ada bandingnya dalam KUHP harus dijatuhkan sanksi sesuai dengan ketentuan KUHP.

\footnotetext{
${ }^{14}$ Imama Sayuti, Dilema Penerapan Hukum Pidana Adat (antara ada dan Tiada), (tanpa tahun), <https://www.kompasiana.com/ dou_rangga/55108453a333112e3cba832a/pidana-adat\#>, [diakses pada tanggal 23/08/2019].
} 
Penerapan Restorative Justice dalam Tindak Pidana Perzinaan pada Masyarakat Kutai Adat Lawas

Selain itu, hukum adat diatur juga dalam Pasal 5 ayat (1), Pasal 10 ayat (1) dan Pasal 50 ayat (1) Undang-Undang Nomor 48 Tahun 2009 Tentang Kekuasaan Kehakiman.

Ketentuan Pasal 5 ayat (1) Undang-Undang Nomor 48 Tahun 2009 Tentang Kekuasaan Kehakiman menyebutkan bahwa:

"hakim dan hakim konstitusi wajib menggali, mengikuti, dan memahami nilai-nilai hukum dan rasa keadilan yang hidup dalam masyarakat. Kemudian Pasal 10 ayat (1) menyebutkan bahwa: pengadilan dilarang menolak untuk memeriksa, mengadili, dan memutus suatu perkara yang diajukan dengan dalih bahwa hukum tidak ada atau kurang jelas, melainkan wajib yang diajukan dengan dalih bahwa hukum tidak ada atau kurang jelas, melainkan wajib untuk memeriksa dan mengadilinya. Berikutnya ketentuan Pasal 50 ayat (1) menyebutkan bahwa: putusan pengadilan selain harus memuat alasan dan dasar putusan, juga memuat pasal tertentu dari peraturan perundang-undangan bersangkutan atau sumber hukum tak tertulis yang dijadikan dasar untuk mengadili."

Oleh karena itu, yang dijadikan ukuran utama menurut hukum adat adalah rasa keadilan dan kesadaran hukum masyarakat sesuai dengan perkembangan keadaan, waktu dan tempat.

Berdasarkan beberapa putusan yang telah dikemukakan tersebut, dapat dikatakan bahwa hakim dalam menjatuhkan putusan terhadap delik adat tetap mengacu pada hukum positif, namun apabila dalam penyelesaian delik adat yang terjadi pihak pelaku dan korban telah menerapkan konsep keadilan restoratif, yang berupa perdamaian, maka penyelesaian secara adat yang telah dilakukan tidak serta merta dapat membebaskan terdakwa dari hukuman pidana. Perdamaian secara adat atau ganti kerugian yang diberikan pelaku kepada korban atau keluarga hanya merupakan dasar pertimbangan hakim yaitu sebagai hal-hal yang meringankan dalam putusan. Dengan kata lain perdamaian yang sudah dilakukan dan santunan yang telah diberikan oleh pelaku kepda korban atau keluarganya hanya untuk meringankan hukuman terdakwa saja, namun dalam kasus tertentu penyelesaian delik adat cukup diselesaikan di tingkat peradilan adat saja dan tidak sampai dilimpahkan ke pengadilan formal.

\section{PENUTUP}

Penyelesaian tindak pidana perzinahan pada Masyarakat Kutai Adat Lawas di Desa Kedang Ipili menerapkan konsep restorative justice, yang medel penyelesaiannya ditentukan oleh ketua adat, atau melalui peradilan adat. Konsep keadilan restoratif ini diterapkan dalam penyelesaian tindak pidana perzinahan yang semata-mata sebagai upaya untuk memulihkan penderitaan yang dialami korban dan untuk memperbaiki keseimbangan dalam masyarakat. 
Bentuk-bentuk penyelesaian delik adat ditempuh melalui beberapa cara yaitu Pelaku perzinahan yang dikenakan adat sumbang (tertangkap basah) terbagi menjadi 4 (empat) macam yaitu muda mudi lajang atau dengan kata lain kedua duanya belum menikah (sama-sama lajang), laki-laki atau perempuan lajang dengan orang yang sudah berkeluarga (salah satu telah menikah), laki-laki atau perempuan yang sama-sama berkeluarga (sama-sama sudah menikah), laki-laki atau perempuan yang sama-sama sudah pernah menikah (dua atau janda). Oleh karena itu, tindak pidana zina menurut hukum pidana adat suku Kutai Lawas melihat bahwa tindak pidana zina mengandung arti yang luas tidak hanya ditujukan kepada orang yang kedua-duanya telah menikah secara sah tetapi ditujukan juga terhadap salah satu pihak yang belum menikah maupun yang telah menikah serta penyelesaiannya dilakukan secara kekeluargaan dan masyarakat suku Kutai Lawas menyetujui putusan adat yang diputuskan oleh pemangku adat. Hal ini dilakukan untuk mengembalikan keseimbangan dalam masyarakat. Selain itu, sanksi bagi pelaku zina bukan berupa sanksi fisik tetapi sanksi yang diberikan adalah hukuman berupa pengganti kerugian atau denda yang dikenakan atas perbuatan yang telah mereka lakukan. Jika kejadian perselingkuhan tersebut terjadi lagi selama 3 (tiga) kali dan yang melakukan adalah orang yang sama maka akan diserahkan ke hukum positif yaitu hukum pidana.

Berdasarkan dengan hal tersebut, peranan hukum pidana adat sebagai hukum tidak tertulis merupakan pembaharuan hukum dan merupakan nilai-nilai hukum pidana adat yang tidak termodifikasi tetapi hidup di tengah masyarakat dan diakui oleh masyarakat adat tersebut.

\section{DAFTAR PUSTAKA}

\section{Buku}

Abdul Manan, Penerapan Hukum Acara perdata di Lingkungan Peradilan Agama Edisi 2, Kencana, Jakarta: 2016.

Djulaeka dan Devi Rahayu, Buku Ajar: Metode Penelitian Hukum, Scopindi Media Pustaka, Surabaya: 2019.

Peter Bang, Papua Berdarah: Kesaksian seorang fotografer di Papua Barat yang lebih dari 30 tahun, BOD-Book on Demand, Jerman: 2018.

\section{Jurnal}

La Jamaa, "Tantangan Modernitas Hukum Pidana Islam", AHKAM: Jurnal Ilmu Syariah, Vol. 2, Juli 2016.

Mia Amalia, "Prostitusi dan Perizinan dalam Perspektif Hukum Islam". TAHKIM Journal Peradaban dan Hukum Islam, 01 (Januari) 2018. 
Penerapan Restorative Justice dalam Tindak Pidana Perzinaan pada Masyarakat Kutai Adat Lawas

Syamsul Huda, "Zina dalam perspektif Hukum Islam dan Kitab Undang-undang Hukum Pidana". Journal Studia Islamika, 12 (Februari) 2015

\section{Peraturan Perundang-Undangan}

Undang-Undang Dasar Negara Republik Indonesia Tahun 1945.

R. Soesilo, Kitab Undang-Undang Hukum Pidana (KUHP) Serta Komentar-Komentarnya Lengkap Pasal Demi Pasal, Politeia: Bogor, 1995.

Rancangan Undang-Undang Hukum Pidana.

Undang-Undang Nomor 48 Tahun 2009 Tentang Kekuasaan Kehakiman.

\section{Sumber Lain}

Imama Sayuti, Dilema Penerapan Hukum Pidana Adat (antara ada dan Tiada), (tabpa tahun), <https://www.kompasiana.com/dou_rangga/55108453a333112e3cba832a/pidana-adat\#>, [diakses pada tanggal 23/08/2019].

Maharaeni Ria Siombo dan Henny Wiludjeng, Hukum adat dalam Pekembangannya, Universitas Katolik Indonesia Atma Jaya, Jakarta: 2020.

Muhammad Abduh Tuasikal dan MSc, "Faedah Surat An-Nuur \#01: Hukuman Bagi Pezina dan Peselingkuh" Rumaysho.Com., (tanpa tahun), <https://rumaysho.com/16274-faedah-surat-annuur-01-hukuman-bagi-pezina-dan-peselingkuh.html>, [diakses pada 20/08/2019].

Mys, "Putusan-putusan yang Menghargai Pidana Adat", (tanpa tahun), $<$ https://www.hukumonline.com/berita/baca/It5746f66360762/putusan-putusan-yangmenghargai-pidana-adat/>, [diakses pada 22/08/2018].

Ni'matul, Khoiriyah, Sanksi bagi pelaku perzinaan dalam Pasal 284 KUHP:Perspektif Hukum Pidana Islam. Diploma thesis, UIN Sunan Gunung Djati Bandung, http://digilib.uinsgd.ac.id/ 8086/6/6_Bab\%203.pdf, [diakses pada 23/08/ 2019].

Tanpa nama, "Arti Kata Zina", Kamus Besar Bahasa Indonesia (KBBI) online, (tanpa tahun), $<$ https://kbbi.web.id/zina>, [diakses pada 30/01/2020].

Wawancara dengan Bapak Sartin selaku penggiat kebudayaan di Desa Kedang Ipil, tanggal 25 Juni 2019. 